\title{
Dry-snow metamorphism expressed by crystal shape
}

\author{
Sergey SOKRATOV, ${ }^{1}$ Nikolai KAZAKOV ${ }^{2}$ \\ E-mail: sokratov@geol.msu.ru \\ ${ }^{1}$ Laboratory of Snow Avalanches and Debris Flows, Faculty of Geography and Natural Risk Assessment Laboratory, \\ Moscow State University, Moscow, Russia \\ ${ }^{2}$ Sakhalin Department of the Far East Branch of the Russian Academy of Sciences, \\ Yuzhno-Sakhalinsk, Russia
}

\begin{abstract}
Dry-snow metamorphism was the focus of extensive investigations in Russia over several decades. Large amounts of data were collected and used to construct a conceptual model based on crystallographic laws. The difference in terminology compared with the conventional model made these results less accessible to the wider international snow science community. This paper attempts to explain this terminology and its background so that the reported findings are not overlooked in ongoing investigations of the driving forces and consequences of snow metamorphism.
\end{abstract}

\section{INTRODUCTION}

The necessity for a common language in the presentation of snowpack observation results is discussed in detail in the International Classification for Seasonal Snow on the Ground (ICSSG; Fierz and others, 2009). A number of national snow classifications have been developed over decades, while for various specific applications the common snow-related terminology is often updated and enhanced. Such variety makes navigation of the international snow-related literature difficult, especially when similar symbols and names with different background or meaning are used in presenting the results of snow investigations (e.g. JSSI, 1998).

The classification systems used in Russia have also evolved over time. While the first attempts to use such a common language involved adoption of the Swiss experience (Molochnikov, 1938), further developments involved other classifications dealing not only with snowpack but also with snow cover, with a view to understanding specific landuse requirements of various Russian territories (Rikhter, 1954; Troshkina, 1992) or specific climatic conditions (Kotlyakov, 1961).

Probably the most fascinating process taking place in natural snow cover is snow metamorphism, determining the snow properties and their spatio-temporal variability. Evidently, description of this process also requires specific terminology and classification. For this reason, Kolomytz (1976, 1977, 1984, 2012) introduced a new classification, rearranged for practical avalanche forecast by Drevilo (1981). This classification is mentioned by Fierz and others (2009) as a 'specialized classification' covering 'temporal evolution of snow in snowpack', which is 'not represented' by the ICSSG. Also, it is used continuously by the presently active part of the Russian snow and avalanche community (Kazakov and Drevilo, 1990; Kazakov and others, 1999; Drevilo, 2000; Lobkina and Mikhalev, 2011). The approach on which this classification is based is used by practitioners for real-time snow avalanche forecast in some units of the Russian Meteorological Service, which unfortunately prevents open publication of investigative results due to security classification. However, the background of the Russian terminology and approach deserves to be brought to international attention and requires explanation, sparsely available in Russian-language or international literature.

\section{THE METAMORPHIC PROCESS (CRYSTAL GROWTH)}

The process of snow metamorphism is normally associated with the process of sintering, incorporating various mechanisms of mass transfer between the ice grains and the effects of settlement (Maeno and Ebinuma, 1983). Another aspect of the metamorphic process is the change in grain shape. The latter is studied quite intensively for crystal growth in clouds (e.g. Bailey and Hallet, 2009), i.e. for separate crystals affected by environmental conditions. For deposited snow the results of similar crystal habit diagrams are very limited (Delsol and others, 1978; Fierz and Baunach, 2000). These are mainly obtained in the laboratory, and the presentation of the observed or expected results of the metamorphic process is normally limited in type either to the grain size (e.g. Sokratov, 2001) or to the grain/bond size evolution (Brown and others, 1999).

Snow-pit observations, despite their structure/destructive character, provide information directly on the grain shapes in each particular snow layer (Fierz and others, 2009). Extensive data, collected by Kolomytz and co-workers (Kolomytz, 1976, 1977), were used to construct a conceptual model of dry-snow metamorphism, based on the law of symmetry (Sheftal' and Kolomytz, 1973; Kolomytz, 1977, 1984, 2012), devoted to the description of the observed temporal phasic changes in crystal shapes. In contrast to the commonly accepted regulation of the metamorphic process by external environmental conditions (temperature, temperature gradient, etc.), the model incorporates the 'internal' forces related to adaptation of natural snow crystals to 'dissymmetric medium' (Kolomytz, 2012). Superposition of external and internal forces in snow results in certain routes of possible evolution, in the case of dry-snow metamorphism corresponding to the scheme presented in Figure 1.

The scheme and the corresponding model were validated in several geographic regions of Russia (West Siberia, Sakhalin, Transbaikalia, Khibiny Mountains, Caucasus Mountains). The most detailed data, including the duration of the stages, were obtained at Sakhalin island and are presented in Table 1. These data show the temporal change in the type of snow according to the scheme (Fig. 1) as a function of the initial properties of snow for a given range of environmental conditions.

The data presented in Table 1 are the generalization of results of numerous repeated snow-pit observations in 


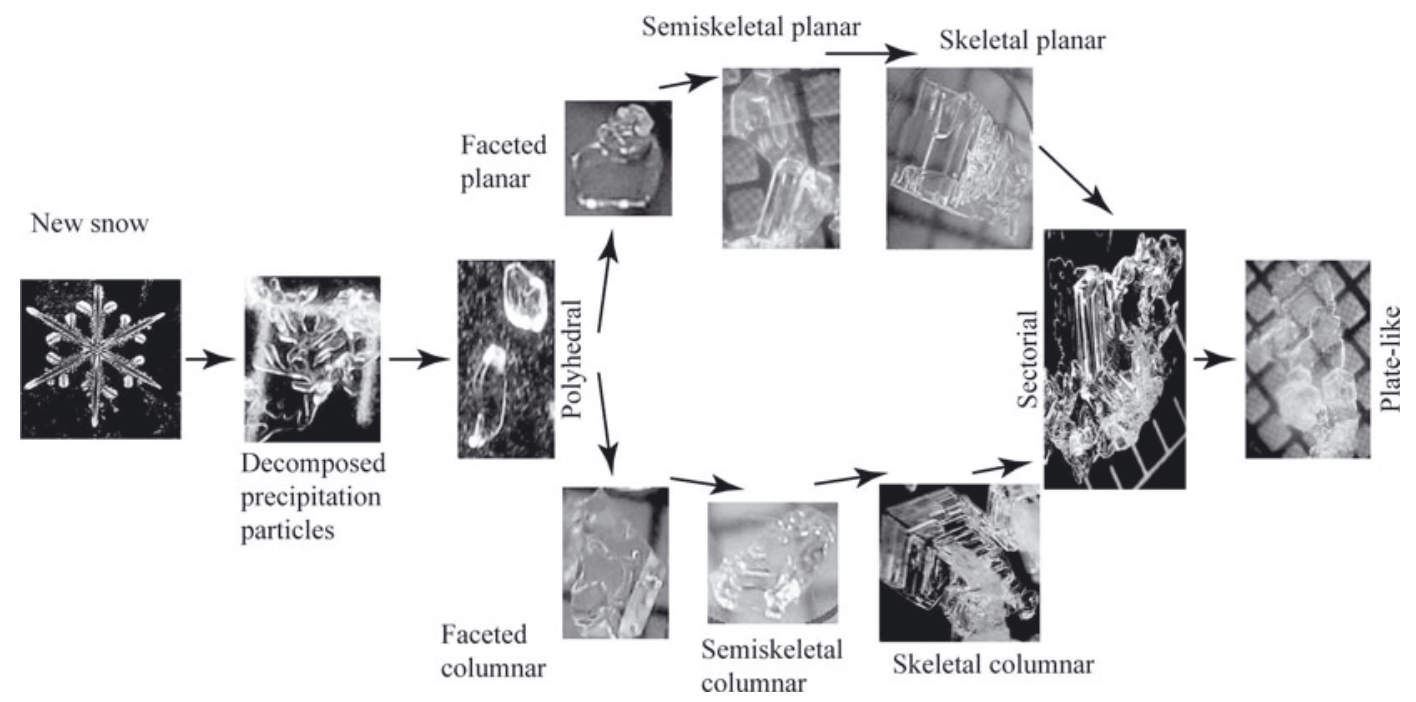

Fig. 1. The stages and routes of crystal growth in dry snow cover.

mountainous regions of south and central Sakhalin. They correspond to snow-cover depths between 55 and $160 \mathrm{~cm}$ (the shallow and deeper snowpacks were found to have different timings of stages) in winters with similar meteorological conditions (presented as temperature ranges in Table 1). Snow layer evolution was monitored below a depth of 20-25 cm (the propagation of the daily temperature variability). The last days in the development are the beginning of the wet metamorphic process and start of the snowmelt season.

\section{TERMINOLOGY}

Clearly, attempts to base snow crystal classification purely on stages of the metamorphic process require terminology and 'boundaries' between the classes, differing from the widely accepted ones. The terms from crystallography gave names that sounded unusual for most of the field snow researchers. However, it is not difficult to relate the classification of the 'temporal evolution of snow in snowpack' represented by the 'morphological classification of crystals in snow cover' (MCC; Kolomytz, 1977, 1984, 2012)

Table 1. The observed average time intervals of the stages of the metamorphic process in snow layers of the snow cover at Sakhalin Island

$\begin{array}{lcc}\text { Initial type of snow: } & \text { New snow } & \begin{array}{c}\text { Corrasion polyhedral Regelation polyhedral } \\ \text { Initial density of snow }\left(\mathrm{kg} \mathrm{m}^{-3}\right):\end{array} \\ 60-80 & 400-500 & 300-350\end{array}$

Evolution due to metamorphism

Symbol Type of snow - class of ice crystal shape
Air temperature range day/night

days

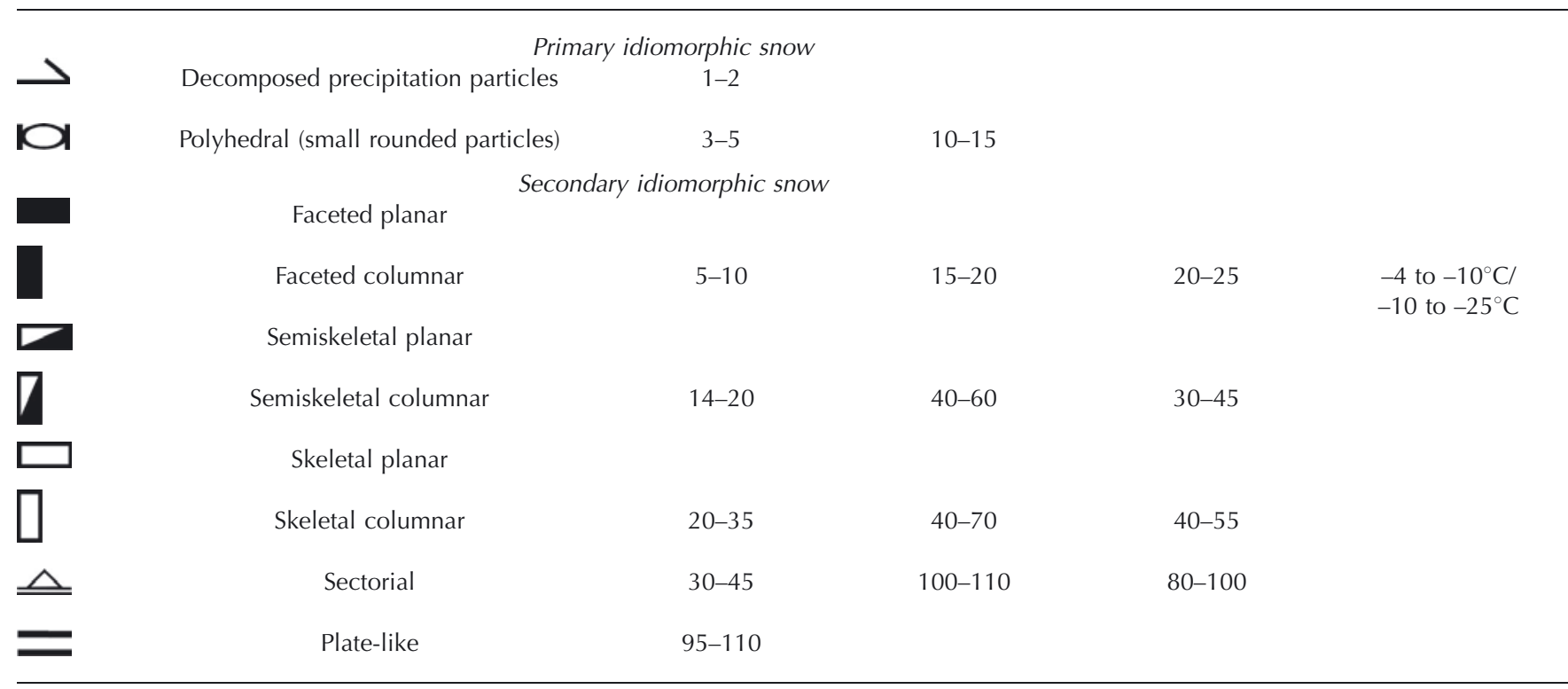


Table 2. The stages of the dry metamorphic process in snow in terminology of the morphological classification of crystals in snow cover, and correspondence to the grain-shape classification from the ICSSG

Morphological classification of crystals in snow cover (MCC)

Grain-shape classification (GSC)

Symbol

Type of snow - class of ice crystal shape

Dry metamorphic Dry metamorphic type stage

Symbol Subclass Metamorphic process

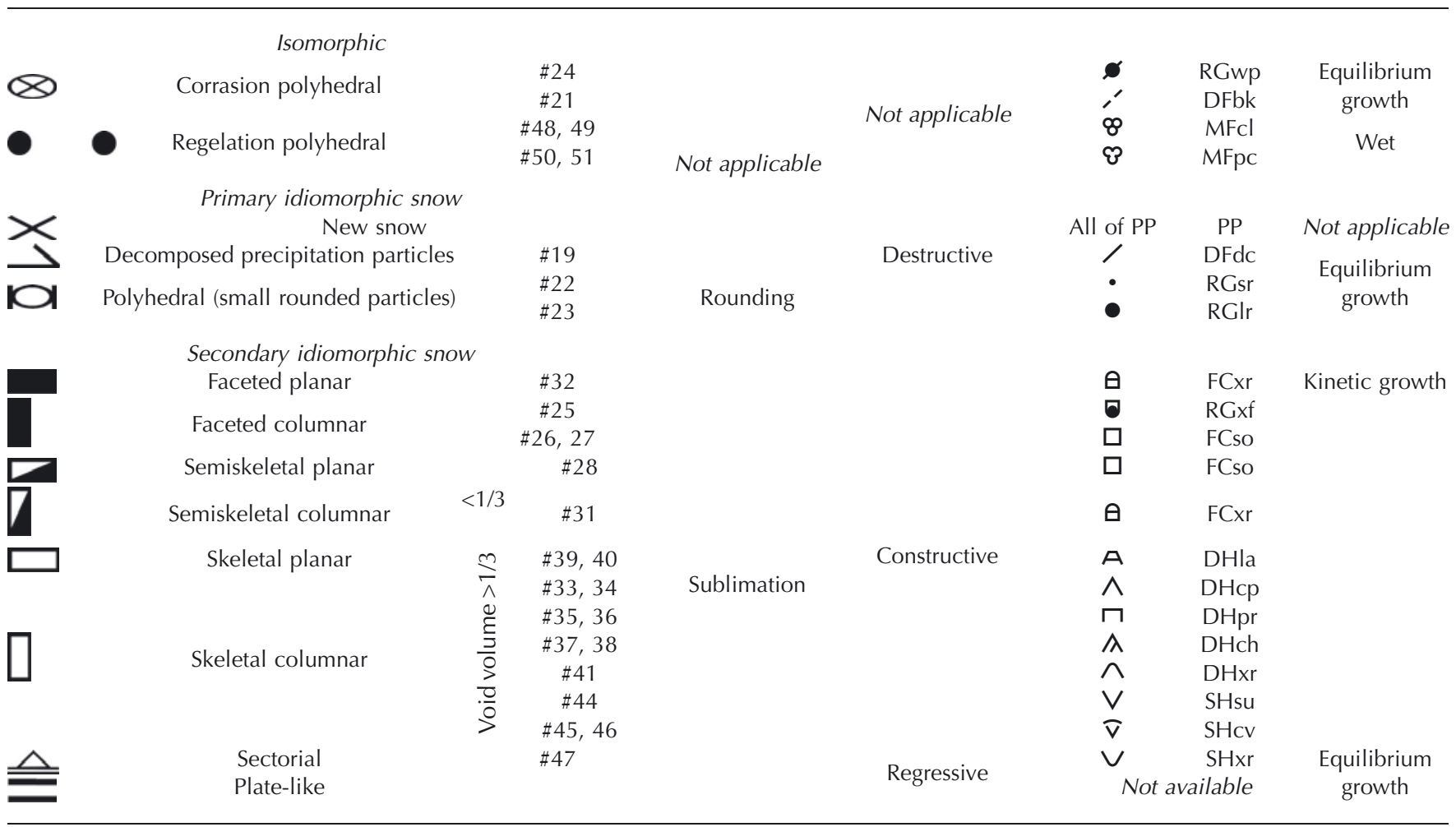

Note: The numbers after number signs (\#) correspond to the photographs of crystals of subclasses in the GSC representing the classes of the MSC when available.

with the grain-shape classification (GSC) developed by Fierz and others (2009) (Table 2).

The difference between the right-hand and left-hand sides of Table 2, in addition to differences in accepted symbols, is the temporal order of shapes in the MCC for the stages of the metamorphic process (Fig. 1). It can be seen that the MCC is more general than the GSC. Focusing on the dry metamorphic process inside the snowpack, some subclasses are missed in the MCC (FCsf, MFsl) and newly introduced in the GSC. The MM class was not of interest in development of the MCC either. It is mentioned in the GSC that detailing is not always possible without knowing the history of the snowpack. For example, recognition between FCsf and FCso and between FCxr and RGxf is expected to be difficult. In the MCC the first pair would be treated as the same shape, while the second corresponds to the same type and stage of drysnow metamorphic process, though the difference is supposed to be visible due to incorporation of the 'planar' and 'columnar' routes of the dry metamorphic process (Fig. 1). The former was found to be the case under lowtemperature conditions $\left(-20^{\circ} \mathrm{C}\right.$ to $\left.-30^{\circ} \mathrm{C}\right)$, while the latter was found at higher temperatures (Drevilo, 1981).

The melt forms are also more schematic in the MCC (Table 3) since these are mainly considered as a stabilizing factor for spring-season snow avalanches (Drevilo, 1981).

The practical use of the MCC includes monitoring of the development of macroscale anisotropic structures in snowpacks (in Russian literature named 'texture'). The anisotropy of natural snowpack resulting from different prevailing processes leading to the recrystallization of snow in different snow layers can be quantified for physical characteristics of snow (e.g. Calonne and others, 2011; Shertzer and Adams, 2011). It is a qualitative observer-dependent measure in field observations, which is why it did not become part of the

Table 3. The crusts and ice formations in terminology of the morphological classification of crystals in snow cover, and correspondence to the grain-shape classification from the ICSSG

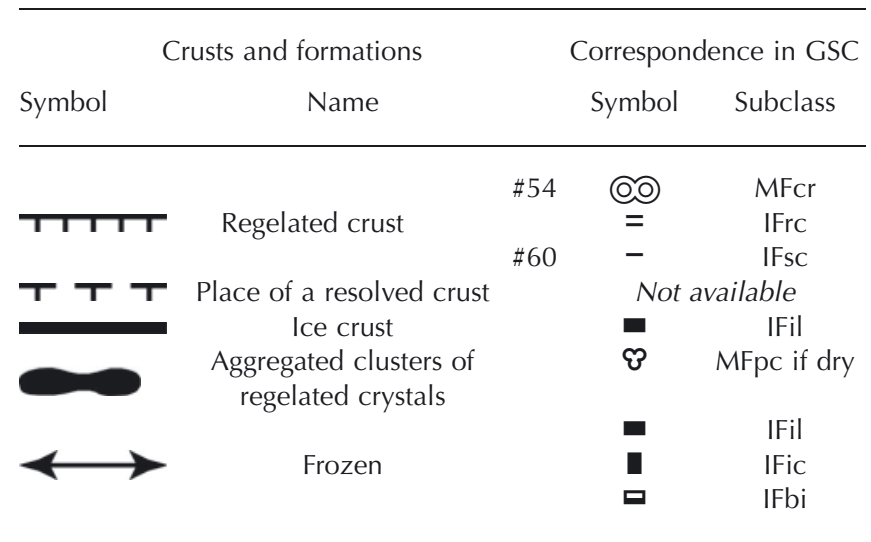

Note: The numbers after number signs (\#) correspond to the photographs of crystals of subclasses in the GSC representing the classes of the MSC when available. 


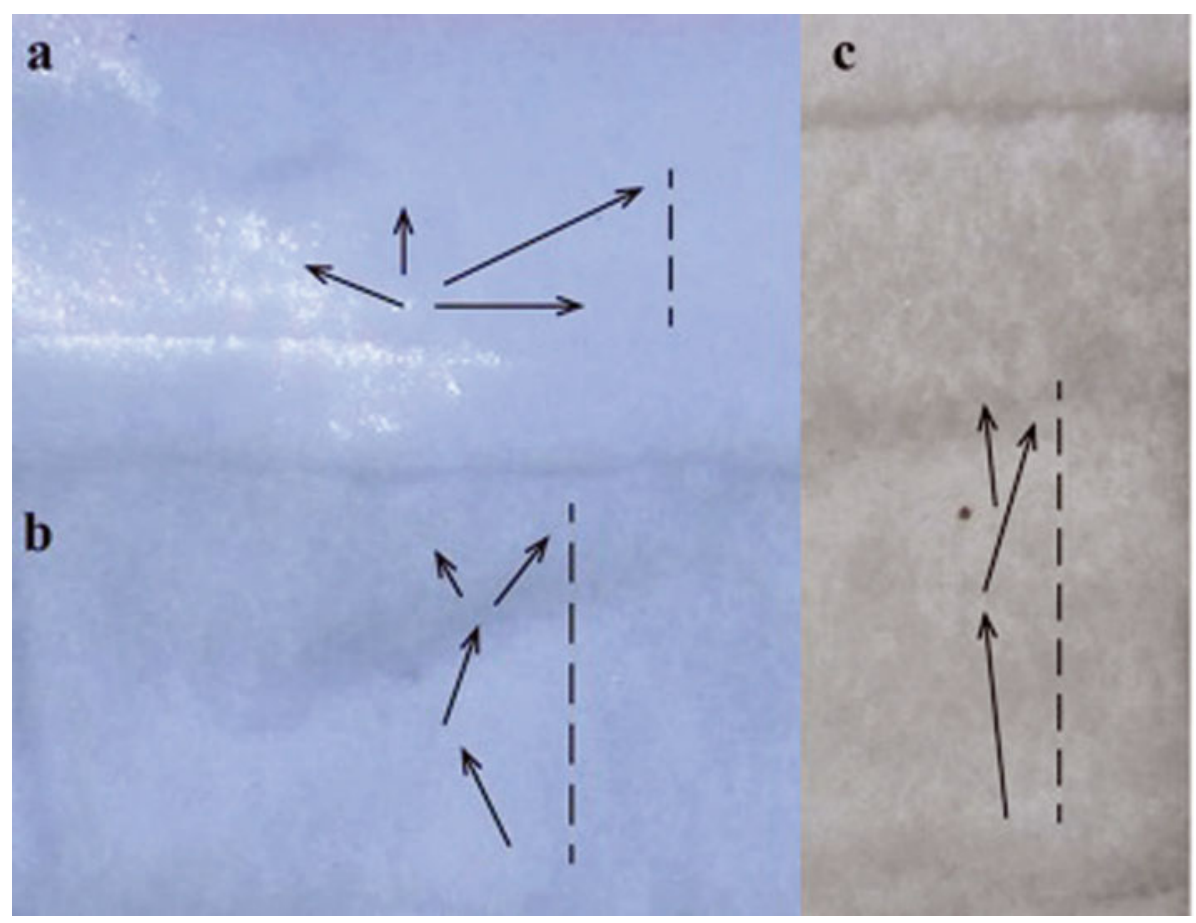

Fig. 2. (a) Monolithic, (b) columnar and (c) fibrous structure ('texture') of snow constructed by semiskeletal and skeletal (Table 2) crystals. Dashed lines show vertical coordinate.

GSC. In the MCC it is determined by semi-subjective ranges of prevailing orientation of optical axes of snow crystals in a snowpack (Table 4) and shows the activity of recrystallization processes used in forecasting avalanche danger. The 'texture' is formed at the secondary idiomorphic phase of snow crystal transformations, and each of the types can be related to some range of possible snow hardness and originally was linked to a particular empirically determined range of tensile strength (Drevilo, 1981).

The monolithic 'texture' corresponds to chaotic orientation of snow crystals in a snow layer. No clusters can be observed, while the grain contact areas are relatively high. The columnar 'texture' is represented by the snow crystals starting to join into clusters oriented vertically as the contact area decreases. The fibrous 'texture' shows clear vertical orientation of clusters of snow crystals. The pore space is also constructed by vertical pores. The contact areas are smaller at vertical faces of ice matrix than at horizontal faces, meaning that the bearing strength of snow cover is decreased together with the visco-plasticity of snow with increasingly fibrous texture. Examples of such anisotropy

Table 4. Types of macroscale anisotropic snow structures ('texture of snow') in the MCC

\begin{tabular}{|c|c|c|c|c|}
\hline \multicolumn{3}{|c|}{$\begin{array}{l}\text { Anisotropy of secondary } \\
\text { idiomorphic snow }\end{array}$} & \multicolumn{2}{|c|}{$\begin{array}{c}\text { Some correspondence } \\
\text { in the GSC }\end{array}$} \\
\hline Symbol & & & Symbol & Subclass \\
\hline \multicolumn{5}{|c|}{ Monolithic } \\
\hline \multicolumn{5}{|c|}{ Columnar } \\
\hline & Fibrous & $\# 37, \# 38$ & $\lambda$ & DHch \\
\hline
\end{tabular}

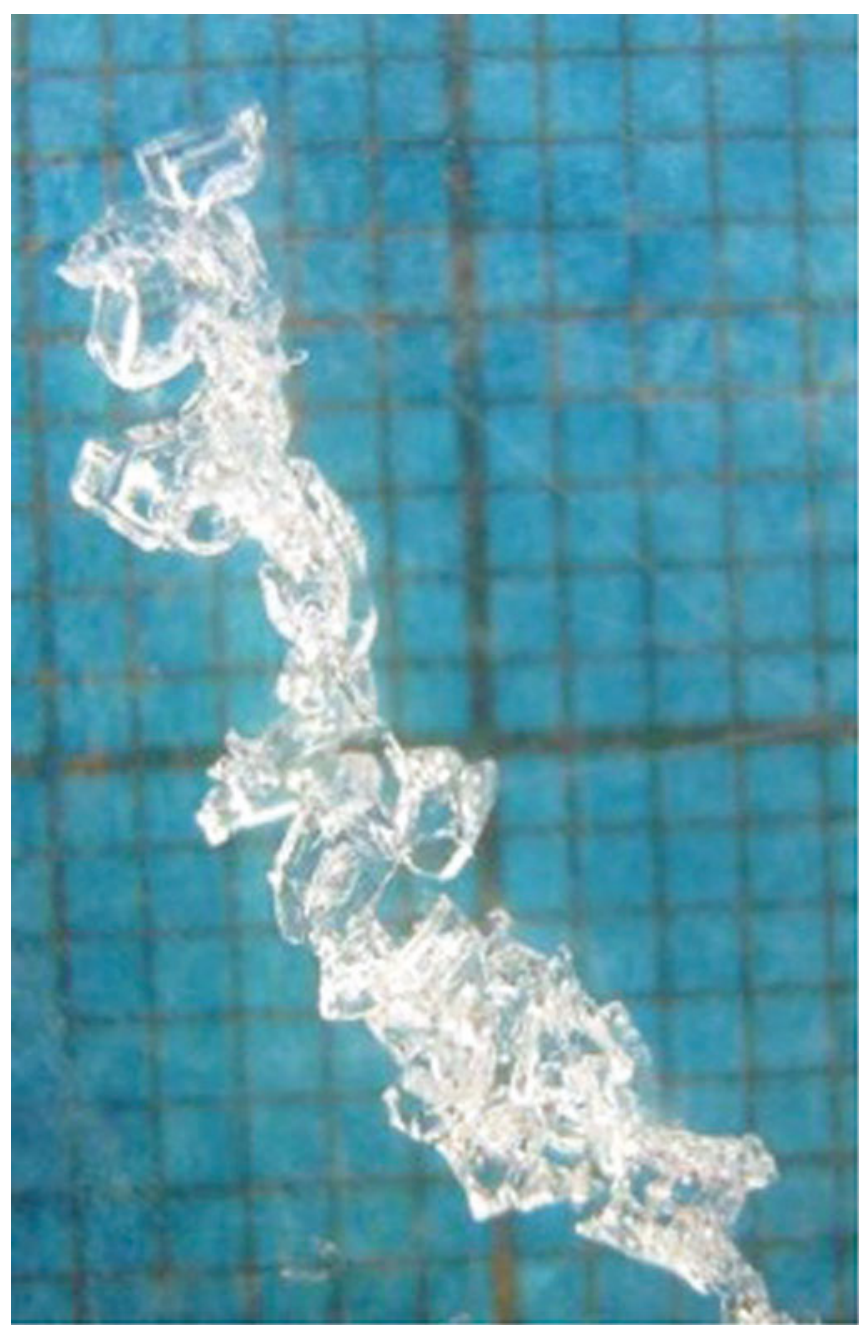

Fig. 3. Cluster of ice crystals of semiskeletal and skeletal shape from the snow layers with fibrous structure ('texture'). 
'measurement' based on 'width to height' of observed macrostructures are shown in Figure 2, with a cluster of snow crystals shown in Figure 3.

\section{DISCUSSION AND CONCLUSIONS}

We have discussed the Russian classification for snow (MCC) and related it to the international classification of Fierz and others (2009; GSC). The classification presented above is not a substitute for the ICSSG (Fierz and others, 2009), but complements it by including metamorphic stages and landscape factors. Direct translation between the two classification systems is possible (Table 2); however, it is not necessarily desirable. Such translation risks deleting a valuable body of information, currently accessible to those familiar with the corresponding background and justification (Kolomytz, 1976, 1977, 1984, 2012).

The recently developed techniques of snow research also present the results in parameters, not well connected to the conventional forms of presentation of the results of snow studies (e.g. Schneebeli and Sokratov, 2004; Painter and others, 2007; Marshall and Johnson, 2009; Gergely and others, 2010). Further development would inevitably introduce new characteristics. Therefore, it becomes especially important in attempts at finding a common language not to lose the existing knowledge, even if presented in terms of different terminology and structure.

Since the description of the dry metamorphic process of snow in the form as presented above has solid empirical back-up, it would most probably be useful to take it into account in further experimental, theoretical and numerical attempts to describe the metamorphic process and its consequences. 'Translation' of the MCC as presented here would make this result less likely to be overlooked in future developments.

\section{REFERENCES}

Bailey MP and Hallet J (2009) A comprehensive habit diagram for atmospheric ice crystals: confirmation from the laboratory, AIRSII, and other field studies. J. Atmos. Sci., 66(9), 2888-2899 (doi: 10.1175/2009JAS2883.1)

Brown RL, Edens MQ and Barber M (1999) Mixture theory of mass transfer based upon microstructure. Defence Sci. J., 49(5), 393-409

Calonne N, Flin F, Morin S, Lesaffre B, Rolland du Roscoat S and Geindreau C (2011) Numerical and experimental investigations of the effective thermal conductivity of snow. Geophys. Res. Lett., 38(23), L23501 (doi: 10.1029/2011GL049234)

Delsol F, Marbouty D, Pahaut E and Pougatch B (1978) Étude de la métamorphose de gradient par simulation en chambre froide. (Note technique de l'établissement d'études et de recherches météorologiques, Nouvelle série 7) Direction de la météorologie, Ministère des transports, Paris

Drevilo MS (1981) O klassifikatsiyakh otlozhennogo snega [On classifications of deposited snow]. Sakhalinskoe UGMS [Sakhalin Administration of the Hydro-Meteorological Service], Yuzhno-Sakhalinsk [in Russian]

Drevilo MS (2000) Struktura snezhnogo pokrova v zonakh lavinoobrazovaniya o. Sakhalina [Snow cover structure in avalanche formation zones of Sakhalin Island]. Mater. Glyatsiol. Issled./ Data Glaciol. Stud. 88, 107-112 [in Russian with English summary]

Fierz C and Baunach T (2000) Quantifying grain-shape changes in snow subjected to large temperature gradients. Ann. Glaciol., 31, 439-444 (doi: 10.3189/172756400781820516)
Fierz C and 8 others (2009) The Intenational Classification for Seasonal Snow on the Ground. IHP-VII Technical Documents in Hydrology 83. UNESCO-International Hydrological Programme, Paris

Gergely M, Schneebeli M and Roth K (2010) First experiments to determine snow density from diffuse near-infrared transmittance. Cold Reg. Sci. Technol., 64(2), 81-86 (doi: 10.1016/ j.coldregions.2010.06.005)

Japanese Society of Snow and Ice (JSSI) (1998) Snow cover classification of the Japanese Society of Snow and Ice. Seppyo, J. Jpn. Soc. Snow Ice, 60(5), 419-436 [in Japanese]

Kazakov NA and Drevilo MS (1990) Avtokolebaniya snezhnogo plasta v lavinosbore, volnovody $v$ snezhnoi tolsche i mekhanism obrazovaniya snezhnykh lavin [Self-excited oscillations of a snow layer in an avalanche catchment and the mechanism of slab avalanche formation]. Mater. Glyatsiol. Issled./Data Glaciol. Stud. 70, 49-57 [in Russian with English summary]

Kazakov NA, Okopny VA, Zhiruev SP, Gensiorovsky YuV and Anikin VA (1999) Lavinnyi rezhim Vostochno-Sakhalinskikh gor [Avalanche regime of Eastern Sakhalin Mts]. Mater. Glyatsiol. Issled. /Data Glaciol. Stud. 87, 211-215 [in Russian with English summary]

Kolomytz EG (1976) Struktura snega i landschaftnaja indikatija [Snow structure and landscape indication]. Nauka, Moscow [in Russian]

Kolomytz E (1977) Metody kristallomofologicheskogo analiza struktury snega [The methods of the crystal-morphological analysis of the snow cover structure]. Nauka, Moscow [in Russian]

Kolomytz EG (1984) Kristallo-morfologicheskiy atlas snega: posobie dlya snegolavinnykh stantsii [A crystal-morphological atlas of snow: a handbook for snow-avalanche stations]. Gidrometeoizdat, Leningrad [in Russian]

Kolomytz EG (2012) Evolutionary conception of snow metamorphism based on crystal morphology and theory of symmetry. Led $i$ Sneg, 3(119), 31-46

Kotlyakov VM (1961) Snezhnyi pokrov Antarktidy i ego rol' v sovremennom oledenenii materika [Snow cover in Antarctic and its role in the present glaciation of the continent]. In Rezul'taty issledovanii po programme Mezhdunarodnogo geofizicheskogo goda [The results of investigations in the program of the International Geophysical Year]. (IX razdel programmy MGG, glyatsiologiya [Section IX of the IGY program, glaciology], No 7). Academy of Sciences of the USSR Publishing, Moscow [in Russian with English summary]

Lobkina VA and Mikhalev MV (2011) Formirovanie tekstury snezhnogo sloya $v$ zavisimosti ot nachal'noi struktury otlozhennogo snega [Formation of snow layer texture depending on initial structure of deposited snow]. Led i Sneg, 2(114), 53-56 [in Russian with English summary]

Maeno N and Ebinuma T (1983) Pressure sintering of ice and its implication to the densification of snow at polar glaciers and ice sheets. J. Phys. Chem., 87(21), 4103-4110 (doi: 10.1021/ j100244a023)

Marshall HP and Johnson JB (2009) Accurate inversion of highresolution snow penetrometer signals for microstructural and micromechanical properties. J. Geophys. Res., 114(F4), F04016 (doi: 10.1029/2009JF001269)

Molochnikov AV (1938) Struktura snegovogo pokrova [Structure of snow cover]. In Tikhomirov El ed. Sneg $i$ snezhnye obvaly $v$ Khibinakh; raion g. Kirovska [Snow and snowslides in Khibiny Mountains; the region of Kirovsk city]. (Vsesoyuznyi gosudarstvennyi gorno-khimicheskii trest 'Apatit', sbornik rabot snezhnometeorologicheskoi sluzhby, vypusk [All-Union State MiningChemical Trust 'Apatit', collected works of the Snow Meteorological Service, issue] I). Gidrometeorologicheskoe izdatel'stvo, Leningrad-Moscow, 15-32 [in Russian]

Painter TH, Molotch NP, Cassidy M, Flanner M and Steffen K (2007) Contact spectroscopy for determination of stratigraphy of snow optical grain size. J. Glaciol., 53(180), 121-127 (doi: 10.3189/ 172756507781833947) 
Rikhter GD (1954) Snow cover, its formation and properties [Snezhnyi pokrov, ego formirovanie i svoistva]. (SIPRE Translation 6). Snow, Ice and Permafrost Research Establishment, Wilmette, IL [Transl. from Izdatel'stvo Akademiia Nauk SSSR, Moscow, 1945]

Schneebeli M and Sokratov SA (2004) Tomography of temperature gradient metamorphism of snow and associated changes in heat conductivity. Hydrol. Process., 18(18), 3655-3665 (doi: 10.1002/hyp.5800)

Sheftal' NN and Kolomytz EG (1973) Evolyutsiya konechnykh form rosta kristallov [Evolution and crystal end forms caused by environmental inclusions]. Acta Phys. Acad. Sci. Hung., 33(3-4), 335-351 [in Russian with English summary]
Shertzer RH and Adams EE (2011) Anisotropic thermal conductivity model for dry snow. Cold Reg. Sci. Technol., 69(2-3), 122-128 (doi: 10.1016/j.coldregions.2011.09.005)

Sokratov SA (2001) Parameters influencing the recrystallization rate of snow. Cold Reg. Sci. Technol., 33(2-3), 263-274 (doi: 10.1016/S0165-232X(01)00053-2)

Troshkina ES (1992) Lavinnyy rezkim gornykh territoriy SSSR [Avalanche regime in mountain regions of the USSR] (VINITI, Itogi nauki i tekhniki, seriya glyatsiologiya, t. [All-Union Institute of Scientific and Technical Information, Outcome of Science and Technology, series Glaciology, vol.] 11). VINITI, Moscow [in Russian] 